\title{
Agents of change in the retail warehouse market
}

Received: 10 October 2003

\section{Mike Taylor}

is Head of King Sturge's Out of Town Retail Group and the Partner in charge of the London Retail Agency Department. He was active in the Out of Town Retail market throughout the UK during the retail warehouse and food superstore booms of the late 1980 s and 1990 .

Mike was also involved in the development of commercial leisure parks during the 1990 driven by the growth of multiplex cinemas and other leisure activities across the UK. More recently he has worked with developers and landowners in the refurbishment and redevelopment of existing parks and the creation of new initiative investment vehicles, such as The Junction.

\section{Andrew Goodbourn}

is employed by King Sturge Financial Services Limited, which is authorised and regulated by the Financial Services Authority for the conduct of investment business. He works in the Investment department concentrating on the indirect investment market and has been involved with the establishment, equity raising and secondary trading for a number of limited partnerships.

\section{Abstract}

This paper examines the consolidation of occupation and ownership within the retail warehouse park property sector and the polarisation of existing schemes towards fashion, bulky goods destination and convenience parks - a process accelerated by continuing occupier and investor demand and a lack of supply, restricted by tighter town planning controls.

Two case studies - Deepdale Park, Preston and St Andrews Quay, Hull - are used to illustrate park evolution and demonstrate the sector's attractiveness to investors and developers, brought together through innovative joint ventures and limited partnerships to facilitate the redevelopment process and create new indirect investment products.

\section{Keywords:}

limited partnerships, indirect vehicles, retail warehouses, destination parks, bulky goods, consolidation, polarisation

Andrew Goodbourn King Sturge Financial Services 7 Stratford Place London $\mathrm{W}_{1} \mathrm{C} 1 \mathrm{ST}$, UK Tel: +44 (o) 2075296719 Fax: +44 (o)20 76294514 E-mail: andrew.goodbourn@ kingsturge.co.uk

\section{INTRODUCTION}

The retail warehouse market is polarising in many ways, largely as a consequence of the restricted supply of new space. There is consolidation of occupation and ownership. Parks of scale increasingly dominate their catchments, repositioning their offer to reflect the nature of sub-regional retailer and consumer demand.

One result has been that investors and developers have been drawn together within innovative joint ventures and limited 


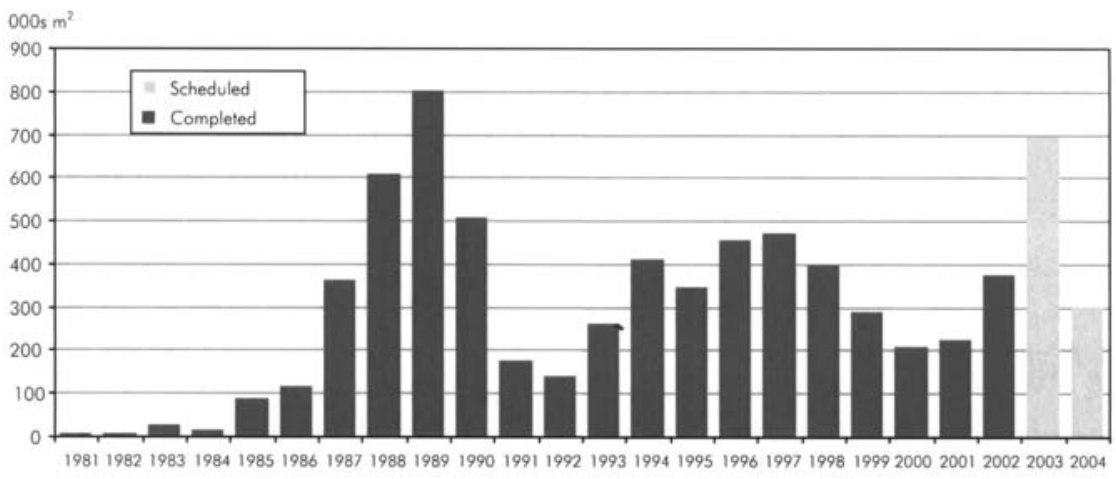

Figure 1: Retail warehouse park openings: Completed and scheduled

partnerships. This paper considers the background to the emergence of this new breed of retail warehouse park owner who has quickened the pace of evolutionary trends in the sector.

\section{DEVELOPMENT SLOWDOWN}

There were two retail warehouse park development booms (see Figure 1). The first in the late 1980s accommodated the consumerled economic recovery of the Thatcher years and was punctuated by the property market collapse of the early 1990s. The second boom, in the mid-1990s, faded upon the publication of John Gummer's revision of PPG6 in 1996. Increasingly, local authorities became sophisticated in the introduction of conditions limiting the range of goods and unit sizes within parks to protect town centres. Recent large parks have tended to be the catalyst for regeneration schemes or the provision of other planning gains, such as sports stadia.

The current legislation is the 1996 PPG6. It continues to protect the vitality and viability of existing centres, as did earlier versions, but introduced the sequential approach in the determination of planning applications for out-of-centre retail developments.

Subsequent ministerial statements have given clarification to the interpretation of the definition of retail need and the application of the sequential approach on each occasion, further restricting the supply of new retail warehouse floor space.

\section{CONSOLIDATION OF OWNERSHIP}

The increasing restrictive interpretation of PPG6 by successive ministers has severely restricted the supply of new retail warehousing accommodation. But, with over a decade of consumer expenditure growth, rental values have increased in the retail warehouse sector during a period when many other property sectors have slowed. This has attracted continued investor interest, strong investment yields, high capital values for single assets and an inertia in which institutions wish to buy but are not prepared to sell prime retail warehouse assets.

Mergers among institutional asset managers and the prohibitively high value of single large retail parks have consolidated the 
Table I: Ownership of retail warehouse floor space

\begin{tabular}{|c|c|c|c|c|c|}
\hline \multirow[t]{2}{*}{ Rank 2003} & \multirow[t]{2}{*}{ Rank 2002} & \multirow[t]{2}{*}{ Rank 200I } & \multirow[t]{2}{*}{ Owner/investment manager } & \multicolumn{2}{|c|}{$\begin{array}{l}\text { Area - million } \\
\text { square feet }\end{array}$} \\
\hline & & & & 2003 & 2002 \\
\hline 1 & 1 & 1 & - Pillar Property & 5.24 & 5.20 \\
\hline 2 & 7 & 5 & $\Delta$ Morley Fund Management & 4.44 & 2.56 \\
\hline 3 & 8 & 8 & $\Delta$ Standard Life Investments & 4.23 & 2.51 \\
\hline 4 & 2 & 4 & $\boldsymbol{\nabla}$ Prudential Property Investment Managers & 4.16 & 3.74 \\
\hline 5 & 4 & 3 & $\boldsymbol{\nabla}$ Land Securities & 3.71 & 3.47 \\
\hline 6 & 5 & 7 & $\nabla$ British Land & 3.53 & 3.18 \\
\hline 7 & 10 & & $\triangle$ Capital and Regional & 3.38 & 2.45 \\
\hline 8 & 3 & 2 & $\boldsymbol{\nabla}$ LaSalle Investment Management & 3.30 & 3.60 \\
\hline 9 & 12 & & $\Delta$ Henderson Global Investors & 3.21 & 2.29 \\
\hline \multirow[t]{2}{*}{10} & 9 & 9 & $\boldsymbol{\nabla}$ Legal and General Investment Management & 2.83 & 2.49 \\
\hline & & & All retail parks & 90.47 & 85.59 \\
\hline
\end{tabular}

Source: FPD Savills Commercial Limited and TW Research Associates 2003

ownership of retail warehouse floor space to only a limited number of owners. Some $90,000,000$ square feet $\left(\right.$ c. $\left.8,400,000 \mathrm{~m}^{2}\right)$ is owned by ten owners out of a total stock of some $150,000,000$ square feet (c. $\left.13,900,000 \mathrm{~m}^{2}\right)$ (see Table 1).

\section{POLARISATION OF PARKS}

The market evolutionary trends suggest that retail warehouse parks are likely to be classified under three broad headings:

- fashion/shopping parks

- destination bulky goods parks

- convenience parks.

Currently there are estimated to be some 850 to 900 retail park locations, and of these perhaps only 35 would presently be classified as fashion/shopping parks. The opportunities to create further shopping parks are limited by the planning process and the market. While there are fewer bulky goods destination parks in existence, there is a potential for perhaps 100 within each of the major conurbations and catchments.

\section{Fashion parks}

These parks require open A1 non-food retail planning permission for a substantial element of the floor space; they are of significant scale, usually in excess of 150,000 square feet $\left(c .14,000 \mathrm{~m}^{2}\right)$ and occupied by high street retailers anchored by the likes of Next, Boots and JJB Sports. They replicate and compete with the high street and regional shopping centres and may be categorised by high margin, high turnover retailing.

Anchors

\section{Bulky goods destination parks}

These have a critical mass often in excess of 200,000 square feet (c. $18,500 \mathrm{~m}^{2}$ ) and are anchored by category killer out-of-centre 
retailers, such as B\&Q, Comet/Currys, DFS and Matalan. They tend to be, but are not exclusively, bulky goods operators in their large store formats offering a range and depth of stock. These operators are characterised by everyday low prices, heavy marketing, low margin and high volume retailing. Other retail warehouse operators seek the comfort of being alongside the anchors, adding critical mass, a wider retail offer and a customer appeal. The destination parks do not compete with fashion parks, the high street or regional shopping centres but attract customers from a much wider catchment than the smaller convenience parks.

\section{Convenience parks}

Convenience parks have less critical mass, typically no more than 125,000 square feet $\left(\right.$ c. $\left.11,600 \mathrm{~m}^{2}\right)$. These parks tend to be occupied by smaller retail formats, eg 35,000 square feet $\left(\right.$ c. $\left.3,250 \mathrm{~m}^{2}\right)$, DIY stores rather than units of 50,000 to 100,000 square feet (c. 4,650$\left.9,300 \mathrm{~m}^{2}\right) ; 10,000$ square feet (c. $930 \mathrm{~m}^{2}$ ) electrical stores rather than 20,000 square feet $\left(\right.$ c. $\left.1,860 \mathrm{~m}^{2}\right)$ plus; secondary retailers and discounters. The retail offer is characterised by low margin, often discounted prices and low volume retailing. These parks service a localised catchment increasingly dominated by a fashion/shopping park and bulky goods destination park in the same area. They have significantly weaker rental performance.

\section{PHYSICAL RECONFIGURATION OF PARKS}

The opportunities for developers are limited by planning restrictions, and specialists in the sector have sought to apply their skills and market knowledge to the existing built stock predominantly in the hands of risk-averse institutional investors.

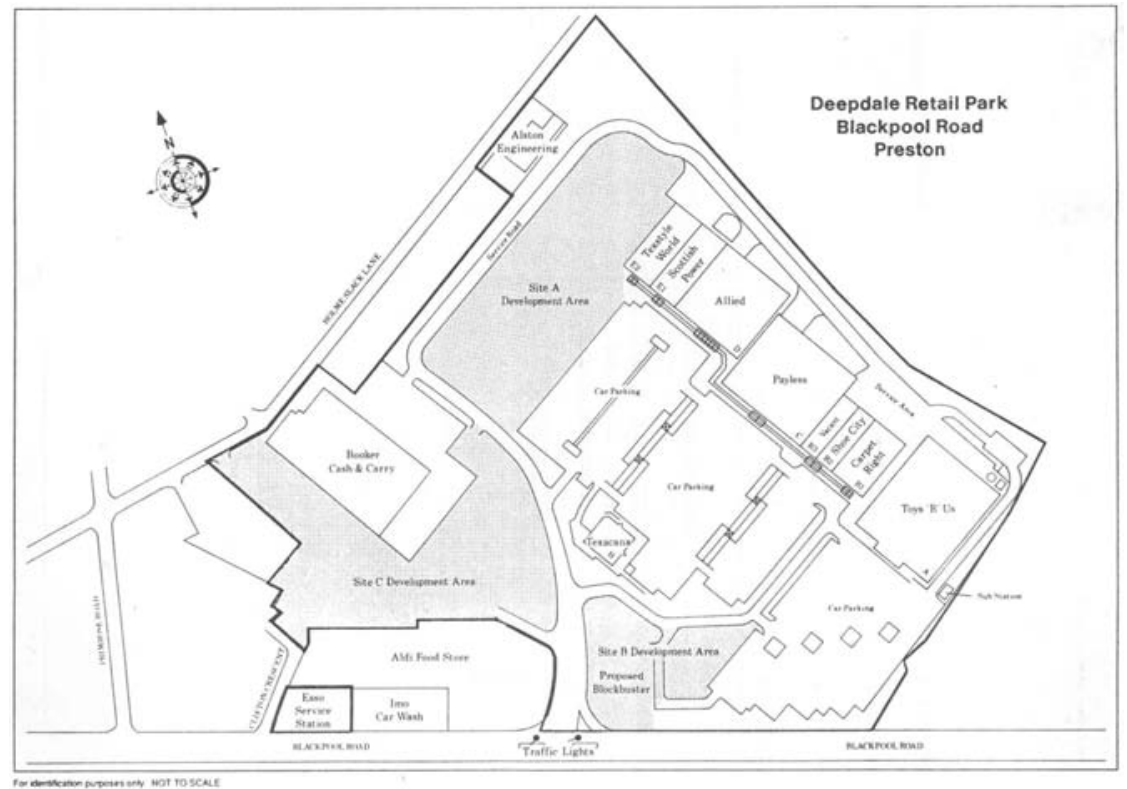

Figure 2: Deepdale before reconfiguration 


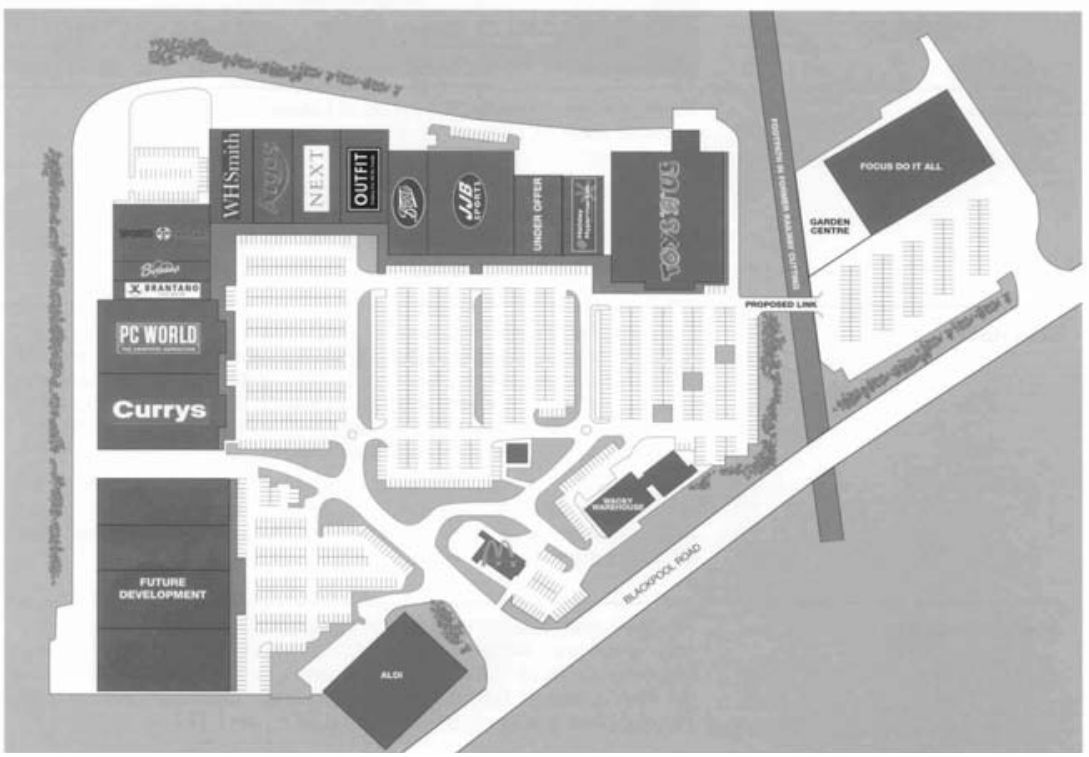

Figure 3: Deepdale existing configuration

Ownership now rests in fewer hands, particularly of the larger assets which are most likely to evolve into fashion and destination bulky goods parks which require scale and critical mass to be successful.

Institutional funds are perhaps by their very nature risk averse, yet the evolution of fashion and bulky goods destination parks needs in many cases radical redevelopment and tenant 'engineering', requiring considerable expenditure and creating short-term income voids and the management of risk, with which the developer is far more comfortable.

The gentrification of retail warehouse parks, remodelled to

Table 2: Deepdale tenants

\begin{tabular}{lllr}
\hline Deepdale tenants $\mathbf{9 9 5}$ & $\begin{array}{l}\text { Floor area } \\
\text { (square feet) }\end{array}$ & $\begin{array}{l}\text { Deepdale existing } \\
\text { tenants }\end{array}$ & $\begin{array}{l}\text { Floor area } \\
\text { (square feet) }\end{array}$ \\
\hline Toys R Us & 43,466 & Toys R Us & 42,652 \\
Carpetright & 10,041 & Holiday Hypermarket & 10,026 \\
Shoe City & 8,025 & Hobbycraft & 10,088 \\
Vacant & 5,000 & JJB Sports & 22,220 \\
Payless DIY & 36,165 & Boots & 13,933 \\
Allied Maples & 25,116 & Outfit & 14,913 \\
Clydesdale Electrical & 10,000 & Next & 10,074 \\
Texstyle World & 10,000 & Argos & 10,123 \\
Texacana Restaurant & 4,500 & WH Smith & 10,086 \\
& & Sports Soccer & 15,254 \\
& & Birthdays & 4,822 \\
& & Brantano & 5,016 \\
& & PC World & 25,073 \\
& & Currys & 25,104 \\
& & Wacky Warehouse & 6,500 \\
Total & & McDonalds & 3,000 \\
& & & Total \\
\end{tabular}




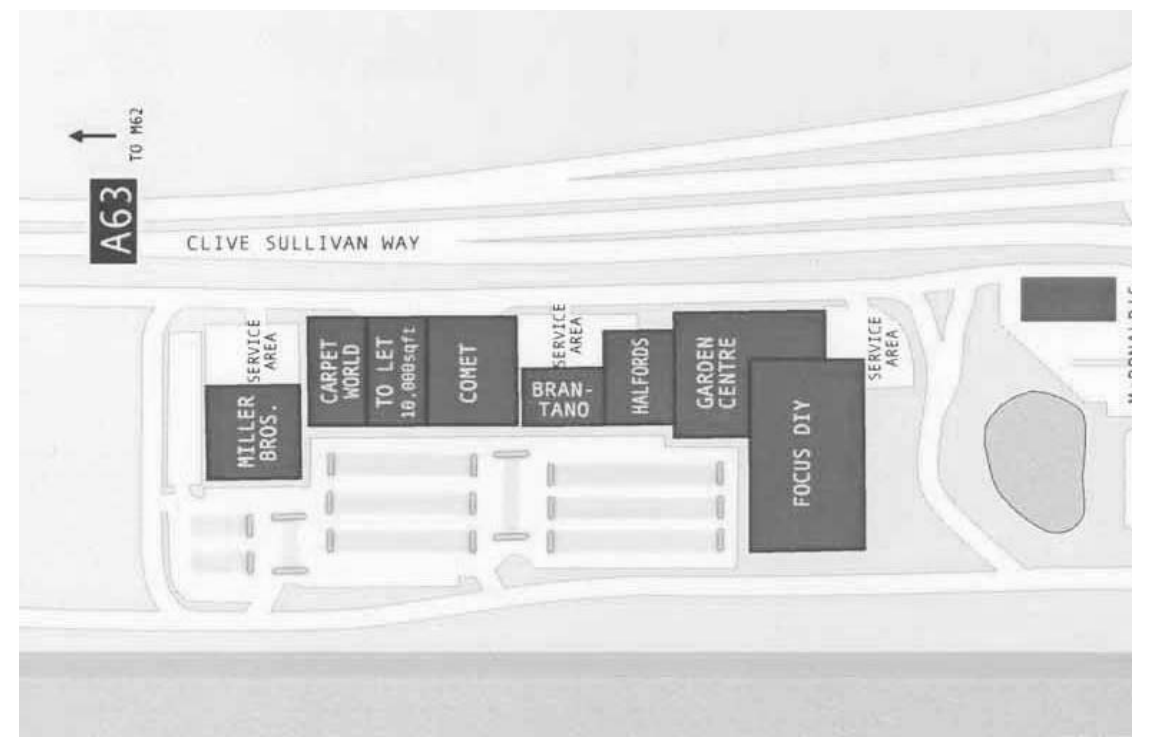

Figure 4: Hull before reconfiguration

accommodate modern retailer requirements, reduced car parking and servicing arrangements has tended to concentrate on those parks constructed in the 1980s' boom which are older, less densely developed and capable of accommodating additional floor space, with more relaxed user restrictions. Two examples are Deepdale Park, Preston (Figures 2 and 3, Table 2), owned by Hercules, a fashion/shopping park, and St Andrews Quay, Hull (Figures 4 and 5, Table 3), owned by The Junction, a destination bulky goods park. The following alterations were carried out at Deepdale, a failing bulky goods retail park, in order to create a fashion park:

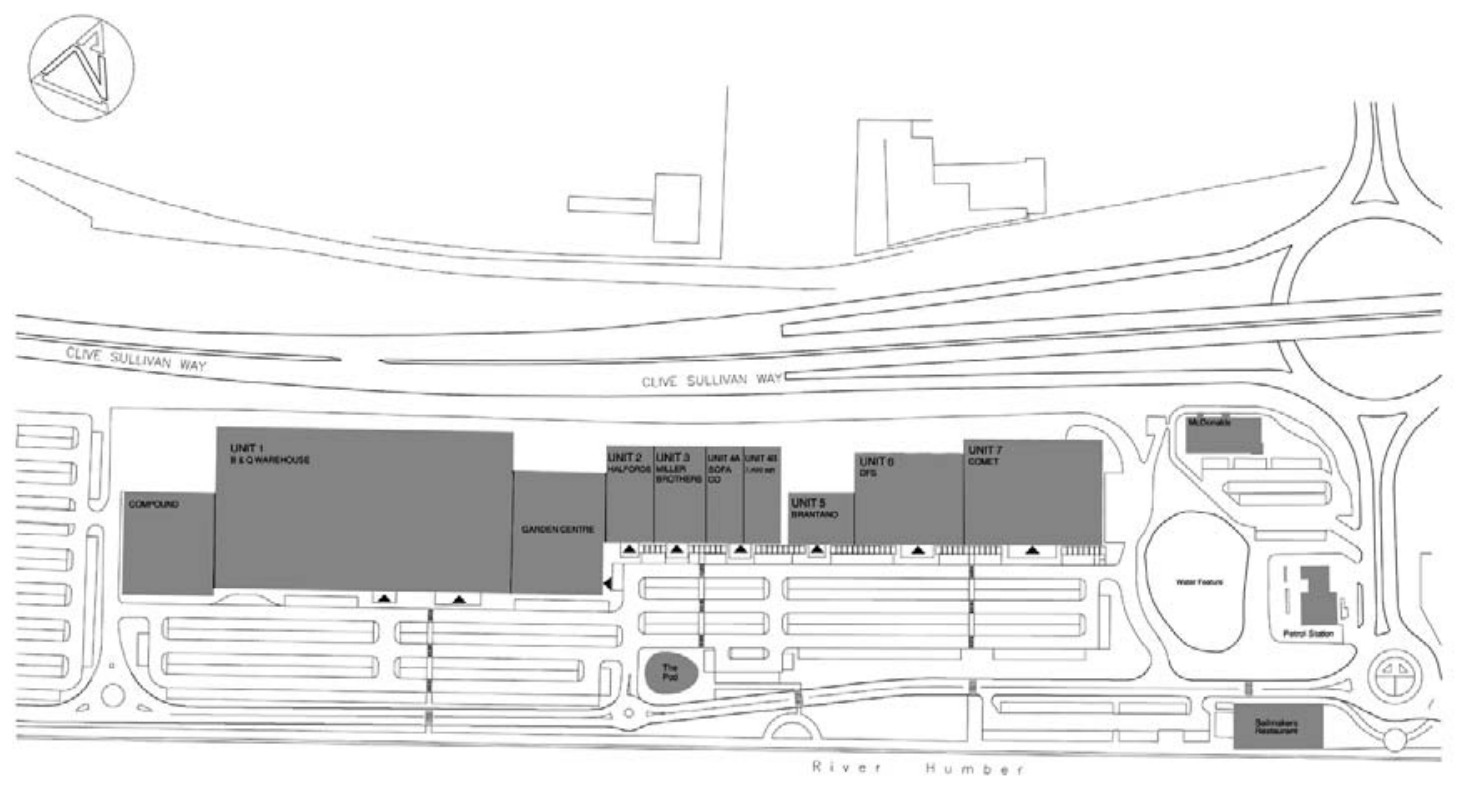

Figure 5: Hull existing configuration 
Table 3: Hull tenants

\begin{tabular}{lllr}
\hline Hull tenants $\mathbf{1 9 9 9}$ & $\begin{array}{l}\text { Floor area } \\
\text { (square feet) }\end{array}$ & Hull existing tenants & $\begin{array}{r}\text { Floor area } \\
\text { (square feet) }\end{array}$ \\
\hline Miller Bros & 10,000 & Miller Bros & 9,877 \\
Carpet World & 10,000 & Carpetright & 7,308 \\
Vacant & 10,000 & Sofa Company & 7,581 \\
Comet & 15,000 & Comet & 30,144 \\
Brantano & 7,500 & Brantano & 6,909 \\
Halfords & 12,423 & Halfords & 10,149 \\
Focus DIY & 35,000 & B\&Q DIY & 102,603 \\
& & ScS & 6,909 \\
& & DFS & 20,036 \\
Total & & & 201,516
\end{tabular}

1. Negotiation of vacant possession of northern terrace (with the extension of Toys R Us).

2. An upper western terrace was constructed on vacant land.

3. The northern terrace was refurbished and let to retailers exploiting open A1 planning permission.

4. A cash-and-carry was acquired to create a lower western terrace.

5. A drive-thru restaurant and bar with childcare was introduced on the main road frontage.

6. A link was created to an adjacent DIY store.

At St Andrews Quay, the following alterations were carried out in order to establish a bulky goods destination park:

1. Millers relocated to a vacant 10,000 square feet unit.

2. Halfords relocated to a unit formerly occupied by Carpet World.

3. Focus agreed a surrender.

4. Former Focus and Miller Bros units were demolished.

5. A B\&Q anchor store was constructed on the Millers site and to the west.

6. A former Halfords unit was extended to accommodate anchor tenant DFS.

7. A new unit was constructed to accommodate Comet in a larger anchor store.

8. The former Comet unit was subdivided.

9. Only Brantano remain in their original location. All units have new external frontage.

\section{LIMITED PARTNERSHIPS AND PROPERTY UNIT TRUSTS: THE AGENTS OF CHANGE}

These vehicles have quickly established themselves to be at the forefront of the retail warehouse sector. The market specialism of the developer has introduced innovative property and marketing management initiatives, creating physical change and adding retail definition to the portfolio. This enthusiasm and innovation is overseen by the experience and analytical disciplines of the institutional fund manager. 


\section{What is the structure?}

The increasing popularity of indirect investment structures such as limited partnerships and property unit trusts within the retail warehouse market enable a developer and an institution to come together for their mutual benefit. This is evidenced by the success of funds such as The Junction (a limited partnership) and Hercules (a property unit trust).

The main characteristics of such vehicles are:

- Tax transparency enabling investors with differing tax liabilities to benefit from the returns produced by a fund, the income of which is not taxed at source

- Gearing enabling those investors prohibited from borrowing themselves (eg pension funds) to benefit from the potentially enhanced returns that gearing can produce

- Specialist management enabling investors to benefit from the skills and expertise of sector-specific asset managers that they could not access themselves; in the case of the retail warehouse market one now sees sub-sector specialisation with an emphasis or focus upon fashion parks (eg Hercules) and bulky goods destination parks (eg The Junction).

Along with the indirect investment vehicles there is also a growing trend for quoted property development companies to transform themselves, taking on more of a fund-level asset management role; Capital \& Regional plc being a prime example with its Junction and Mall funds.

A developer and an institution may become partners in these vehicles, based on the former contributing a significant part of its retail warehouse development portfolio and the latter putting in partly property, partly cash to fund both developments and future acquisitions. As the fund grows, further capital is raised by bringing in new investors who take a passive role in the venture as either a limited partner or a unit holder.

\section{BENEFITS FOR THE DEVELOPER}

\section{Additional stock}

In a polarising retail warehouse market with severely restricted supply, this process gives the developer the chance to increase the size of their portfolio through the addition of assets from an institutional partner.

\section{Additional finance}

The raising of additional funds to carry out development is enabled through the new equity invested in the vehicle by the institutional partner and any additional future investors. With the quoted property sector's shares continuing to trade at significant discounts to net asset value, additional finance has not been forthcoming from the traditional capital markets. 
Agents of change in the retail warehouse market

\section{Regular income flows}

Retail warehouse developers' income is traditionally affected by the inconsistencies and uncertainties of the planning process. With the formation of funds such as The Junction and Hercules, the developer can now benefit from a regular income flow from asset management fees charged to the new vehicle. Additional income can be achieved through a performance fee paid subject to out-performance of the relevant Investment Property Databank benchmark.

\section{Diluted risk}

The developers' income is not solely dependent upon planning/ development success but is also received from asset management activities. Time becomes less critical. Developments are funded through borrowings and income secured on a much larger portfolio. The individual developments are a much smaller element of the enlarged income-producing portfolio.

\section{BENEFITS FOR THE INSTITUTIONAL PARTNER}

\section{Enhanced portfolio}

The fund manager now has a greater variety of stock to manage at a fund level. Parks formerly held by the fund alone are more rapidly transformed into market-leading flagship parks through the asset management initiatives undertaken as part of the new vehicle's business plan.

\section{Innovative relationships}

By coming together in the new vehicle, the fund is able to develop a close working relationship with an innovative and entrepreneurial sector-specialist developer and to benefit from the characteristics of such, characteristics not usually associated with institutional funds.

\section{Control risk}

Through the diversity of the portfolio and the market knowledge and expertise of the developer, the fund is now able to benefit from being party to an element of controlled development risk. With the size of individual assets becoming larger and larger, the fund is able to spread the risk of performance of an individual asset through the overall portfolio return.

\section{Exposure to development}

Larger, older parks present an opportunity upon redevelopment to secure additional retail warehouse floor space, satisfying a fund objective without competing for such products in the open marketplace. For development properties, the fund is effectively taking the pre-funding role at the earliest possible stage and will therefore benefit from an increased return.

\section{Additional income}

The fund will charge the new vehicle a fund management fee for 
undertaking the necessary regulatory role and being responsible for high-level decision making, financing and reporting to additional investors.

\section{Gearing}

Improved returns for the fund come not only from the sectorspecialist asset management skills of the developer but also from the ability to leverage the portfolio, which they are unable to achieve outside these types of vehicle.

\section{CONCLUSION}

The drivers of market evolution and the proactive focus of the specialist vehicles mentioned above have, first, accelerated the physical polarisation of parks through active refurbishment and redevelopment programmes. Secondly, they have established much closer relationships between the sector-specialist landlords and tenants than have previously been seen in the industry. This relationship highlights the common objective to improve the retail offer and customer appeal through management and marketing initiatives more closely associated with factory outlets and shopping malls. These strategies include creating a customer focus and orientation through the introduction of non-retail attractions, banking facilities, toilets, cafés, on-site management and security and localised marketing. These initiatives help both to attract and to prolong customer visits.

The success of these vehicles as an investment product will continue to attract institutional investment but the sector is also seeing more private and high net worth individual investors being given the opportunity to benefit from the performance of these funds (eg Hercules). In the future it is likely that one will see these types of vehicle increasingly made available as a way for the 'man in the street' to invest in property as he would in equities. 